\title{
How do Stocks in BRICS co-move with Real Estate Stocks?
}

\author{
Luis A. Gil-Alana ${ }^{1}$ OlaOluwa S. Yaya ${ }^{2}$ Omokolade Akinsomi $^{3} \quad$ Yener Coskun $^{4}$
}

\begin{abstract}
This paper investigates BRICS markets' integration and segmentation between real estate indices and stock indices, and the possibility of establishing "wealth" and "credit" effects. The analysis of the relationship is based on updated techniques in time series using the concepts of fractional integration and cointegration and Granger causality. This allows us to look at bi-directional long-run equilibrium relationships between the two variables in the five countries. The results indicate that all the series are highly persistent, with orders of integration around 1 . However, we do not find any evidence suggesting long run equilibrium relationships between the real estate stock indices and the stocks indices. Meanwhile, causality is bi-directional in the case of South Africa, thus both "wealth effect" and "credit effect" exist, while only "credit effect" is established in India and Russia.
\end{abstract}

Keywords: Credit and wealth effects; Fractional integration; fractional cointegration; BRICS, countries, real estate indices

JEL Classification: C22; C50; R30, R39

\footnotetext{
${ }^{1}$ Universidad de Navarra, Facultad de Ciencias Economicas, Edificio Biblioteca, Entrada Este, E-31080 Pamplona, Spain and Universidad Francisco de Vitoria, Madrid, Spain. E-mail: alana@unav.es

${ }^{2}$ University of Ibadan, Department of Statistics, Mathematics and Statistics Complex, The University of Ibadan, Nigeria. E-mail: o.s.olaoluwa@gmail.com

${ }^{3}$ University of the Witwatersrand, School of Construction Economics and Management, 1 Jan Smuts Avenue, Johannesburg, South-Africa, 2001. E-mail: kola.akinsomi@wits.ac.za

${ }^{4}$ Capital Markets Board of Turkey, Capital Markets Board of Turkey, Eskişehir Yolu, Ankara 06530, Turkey. E-mail: yener.coskun@spk.gov.tr
} 


\section{Introduction}

As far back as 1980, portfolio managers and institutional investors, such as real estate managers started developing a significant interest in financial risk management. Portfolio managers consider various risk reduction strategies, and hence establish the benefits of diversifying portfolios. Real estate is tangible with low volatility, and in addition, its income generating potential is robust (Anoruo and Elike, 2015). Thus, both stock and real estate are important asset prices in household portfolios. Real estate marketing involves exchange, lease, mortgage or transfer of pieces of real estate and the right to use them according to market regulations. According to Petrova (2010), part of the credit cycle running from increasing stock price to increasing real estate price is termed "wealth effect", in the sense that increasing stock prices cause increasing market capitalization which leads portfolio managers to invest more in portfolios, and as well to re-invest more in real estate. This subsequently leads to a higher demand for houses and thus, increasing real estate prices. If, on the other hand, increasing real estate price triggers increasing stock price, this contagion is termed as "credit effect", in the sense that higher collateral value is involved and growths in production and trade are triggered, which subsequently increases expected profits.

Real Estate stocks are important indicators when constructing equity of fixedincome portfolio in the sense that they provide greater diversification, higher returns and lower overall risk. In this paper, we investigate co-movements between real estate prices and stock prices by using a fractional cointegrating framework. Specifically, we carry out a battery of methods based on fractional integration and cointegration and causal relationship tests using Granger Causality. The essence of Granger Causality is to test the direction of causality, that is to establish possible "wealth" and or "credit" effects, which have important 
policy implications for real estate managers, and other policy makers. Thus, we consider the two hypotheses:

H1: An increase in stock prices will cause a corresponding increase in real estate prices, and this provides support for the "wealth effect".

$\mathrm{H} 2$ : An increase in real estate prices will lead to an increase in stock prices, providing support for the "credit effect".

The rest of the paper is structured as follows: Section 2 reviews the literature on cointegration relationships and causality between stocks and real estate indices. Section 3 describes the data and presents the results of this work, while Section 4 renders concluding remarks and future extensions of the work.

\section{Literature Review}

Quite a number of articles have investigated the interrelationships between real estate and stock indices, and the analysis has generally been based on cointegration, informed as a result of unit integration in stock and real estate indices. Using cointegration, they were able to detect possible "wealth effect" and "credit effect" contagions between the two markets.

Liu et al. (1990) obtained evidence of market segmentation between real estate and the stock market, while Gyourko and Keim (1992) reported contradictory findings, obtaining evidence that S\&P500 stock returns have significant explanatory power in predicting equity REIT returns. Liu and Su (2010) applied asymmetrical threshold cointegration tests to investigate the existence of a long run non-linear relationship between the Shenzhen Composite Index of China and the real estate price index. These authors found the existence of "wealth effect" in the short run as indicated by the results of the Granger Causality test, while in the long run, they observed the existence of the "credit price" effect, above the threshold for the "wealth effect", implying a bidirectional causal relationship. 
Generally, their empirical results demonstrated non-linear and asymmetric price transmissions between the two markets in the long run. Similarly, Lin and Lin (2011) investigated the integration relationship between real estate markets and stock markets in six Asian economies: China, Hong Kong, Japan, Singapore, South Korea and Taiwan. Their results indicated strong integration between real estate and the stock markets in Japan, while weak integration was obtained in the cases of China, Hong Kong and Japan, implying that real estate and stocks are substitutable, while potential diversification for investment was found for South Korea and Singapore.

Tsai, Lee and Chiang (2012) applied a threshold error correction model to examine the cointegrating relationships between REITs and stocks with consideration for asymmetry, in Australia, Japan, Singapore, Taiwan, Korea and Hong Kong. The results obtained showed a significant long-run equilibrium relationship between REITs and stocks in most of these markets. Furthermore, causal tests revealed that previous market information about stock predicted changes in REITs in all the markets, and the causality was bidirectional when the full sample was used. During the sub-prime and mortgage crisis periods, however, one way causality was detected and the REIT indices had more influence on stock indices after the sub-prime mortgage crisis period. Lin and Fuerst (2014) studied the long-term association between stock and real estate markets in nine Asian countries for the period 1980 - 2012. Using linear and non-linear cointegrating techniques, evidence of linear unit cointegration of stocks and the real estate index was observed in the case of Taiwan, fractional cointegration was observed in Singapore and Hong Kong, and no evidence of cointegration was observed in the case of China, Japan, Thailand, Malaysia, Indonesia and Korea. Chang, Fang and Lee (2015) applied an Autoregressive Distributed Lag (ADL) threshold cointegration model to investigate a long run equilibrium relationship between REITs and 
stock markets in Japan and Singapore, and the results showed significant evidence of long run relationships between the markets.

Pandey and Jessica (2016) applied Johansen cointegration and Granger Causality tests in a Vector AutoRegression (VAR) framework to establish the role of real estate in a multi-asset portfolio in India. Having considered quarterly data from the first quarter of 2009 to the third quarter of 2017 for real estate index and NSE 50 index, the results obtained showed no evidence of long run causality, as well as no significance of a short run relationship between the two markets. Thus, segmentation exists between the two markets and assets can be held in a portfolio for diversification purposes.

Yuksel (2016) considered post 2007 Turkish market behaviour on real estate prices and stocks in a threshold cointegrating framework. The results obtained, based on the cointegrating approach, showed that both wealth and credit-price effects existed in the Turkish market during the pre-crisis period, while only a credit-price effect existed during the crisis period.

Wang et al. (2017) applied a linear cointegrating model and a time-varying vector error correction model to explore a possible long run relationship between the real estate market and the stock market in Taiwan. The results of both cointegration tests showed no evidence of linear or non-linear cointegration, suggesting that REIT markets are segmented from the stock markets. Finally, Lee et al. (2017) studied the links between Australian house prices and stock prices by means of Toda and Yamamoto's (1995) approach to the Granger causality test. The work was aimed at investigating capital switching effects between house prices and stock prices. The results provide evidence of a negative lead-lag relationship between stock prices and house prices in Australia, suggesting the existence of capital switching activities between the two assets. 
The differences in the methodologies applied in the previous works have led to different empirical results being obtained. The majority of these works are based on unit roots and cointegration tests which use integer degrees of differentiation and do not consider potential fractionally integrated values.

\section{Methodology}

The methodology employed in this paper is based on the concepts of fractional integration and cointegration. For a review, see Gil-Alana and Hualde (2009). By fractional integration, we mean that the number of differences required in a series to be covariance stationary and $\mathrm{I}(0)$ is a fractional value. In other words, a series may be neither stationary $\mathrm{I}(0)$ nor $\mathrm{I}(1)$ but integrated of order $\mathrm{d}$, where $\mathrm{d}$ is a fractional value that might be constrained between 0 and 1 , or even above 1 . In this context, the (fractional) differencing parameter, say d, will be an indicator of the degree of persistence in the data since the higher the value of $d$ is, the higher the degree of persistence between the observations is.

Using the standard notation, we say that a process $\left\{\mathrm{x}_{\mathrm{t}}, \mathrm{t}=0, \pm 1, \ldots\right\}$ is integrated of order $\mathrm{d}$ (and denoted by $\mathrm{I}(\mathrm{d})$ ) if it can be represented as

$$
(1-L)^{d} x_{t}=u_{t}, \quad t=0, \pm 1, \ldots
$$

where $\mathrm{L}$ is the lag operator (i.e., $\mathrm{L}^{\mathrm{k}} \mathrm{x}_{\mathrm{t}}=\mathrm{x}_{\mathrm{t}-\mathrm{k}}$ ) and $\mathrm{u}_{\mathrm{t}}$ is $\mathrm{I}(0)$ defined as a covariance stationary process satisfying the property that the infinite sum of the autocovariacnes is finite. Thus, if $d=0$ in (1), $x_{t}$ is short memory or $I(0)$; if $d$ belongs to the interval $(0,0.5)$, the process is long memory though stationary; interestingly we can also have nonstationarity and mean reverting behaviour if $\mathrm{d}$ belongs to the interval $[0.5,1)$, while lack of mean reversion occurs if $\mathrm{d}=1$ or $\mathrm{d}>1$. Therefore, under the $\mathrm{I}(\mathrm{d})$ structure, we have a large degree of flexibility in the dynamic specification of the models. 
The I(d) class of models was introduced in the early 80 s by Granger $(1980 ; 1981)$ and Granger and Joyeux (1980) though it was not applied until the late 90s and the beginning of the 2000s when these models become very popular in the analysis of aggregate economic and financial data. Examples are the papers by Baillie (1996), Gil-Alana and Robinson (1997), Lobato and Savin (1998), Michelacci and Zaffaroni (2000), Gil-Alana and Moreno (2012), Abbritti, et al. (2016), etc.

Once fractional integration is defined, its natural extension is the case of fractional cointegration. In the simple bivariate case, given two individual series which are both integrated of order $\mathrm{d}$, and denoted as $y_{1 t}$ and $y_{2 t}$, if there exists a linear combination of the two, i.e, $y_{1 t}-\alpha y_{2 t}$, which is integrated of order $d-b$ (i.e., $I(d-b)$ with $b>0$, we then say that the two series cointegrate and $(1, \alpha)^{\mathrm{T}}$ is then called the cointegrating vector. Though Engle and Granger (1987) introduced this concept for any real values $d$ and $b$, the empirical applications carried out in the following years focussed exclusively on integer orders of integration, namely $d=b=1$, implying that the individual series are $I(1)$ and the cointegrating relation is $I(0)$. Cheung and Lai (1993) and Gil-Alana (2003) among others investigated the case of fractional degrees of differentiation and it was later when Peter Robinson and his co-authors extended the theoretical concept of cointegration to the fractional (long memory) case. (Robinson and Marinucci, 2001, Robinson and Yajima, 2002; Robinson and Hualde, 2003; Hualde and Robinson, 2007, 2010; etc.). ${ }^{1}$

\section{Data and Empirical Results}

\footnotetext{
${ }^{1}$ In a more general context, Johansen and Nielsen $(2010,2012)$ extended the cointegrated VAR (CVAR) approach to the fractional case (FCVAR).
} 
We considered daily time series of real estate indices and stock price indices for BRICS (Brazil, Russia, India, China and South Africa). By using the usual nomenclature for real estate indices from Bloomberg, we named BRICS real estate indices as follows: ENEIBRU (Brazil), ENEIRUU (Russia), ENEIINU (India), ENEICNU (China) and ENEIZAU (South Africa), while the corresponding stock indices are: Ibovespa Brasil Stock Exchange (IBOV), Russian Trading System Cash Index (RTSI), Bombay Stock Exchange (SENSEX), Shanghai Stock Exchange Composite Index (SSEC) and Johannesburg Stock Exchange (JSE), respectively. The data sample span from 19 March 2012 to 08 November 2017.

\section{[Insert Figure 1 about here]}

Figure 1 displays the time series data. From the plots of ENEIBRU and Ibovespa (Brazil), we observe that the two series have moved together in the same direction since 2013. For ENEIRUU and RTSI (Russia), the series moved in the same direction from 2012 and then start diverging. Similarly for India (ENEIINU and SENSEX), there is general divergence towards the end of the sample. For China (ENEICNU and SSEC) there was a convergence around 2012 and the series later maintained similar fluctuations toward the end of the sample. South Africa real estate index (ENEIZAU) fluctuates with the JSE index from the beginning of the sample, though the margin becomes wider towards the end of the sample. Generally, these series indicate possible co-movements within the sampled period examined.

We start by examining the individual behaviour of the series, and for this purpose, we consider the following (univariate) model,

$$
y_{t}=\beta_{0}+\beta_{1} t+x_{t}, \quad(1-L)^{d} x_{t}=u_{t}, \quad t=1,2, \ldots .
$$

where $y_{t}$ is the observed time series; $\beta_{0}$ and $\beta_{1}$ are the coefficients corresponding to the intercept and the linear time trend, respectively, and $\mathrm{u}_{\mathrm{t}}$ is $\mathrm{I}(0)$ as described above and 
presented, for the purpose of the present work, as a simple white noise and autocorrelated in turn; in the latter case, using the exponential spectral model of Bloomfield (1973), which is a non-parametric way of describing the autocorrelation with the values decaying exponentially fast as in the AR(MA) case. $^{2}$

\section{[Insert Table 1 about here]}

Starting with the case of uncorrelated errors, we observe that the time trend is only required in a number of cases, in particular, for the stock prices in India (SENSEX) and South Africa (JSE); in all the other cases, the intercept seems to be sufficient to describe the deterministic terms. Focussing on the value of $d$, we note that the values are slightly higher for the ENEIs than for the stocks, and also higher with no autocorrelation than when autocorrelation is allowed. In general, the values are around 1, in some cases above and in some others below. For the case of autocorrelated errors, the I(1) hypothesis cannot be rejected in practically any case, the only exceptions being the two series for South Africa (SENSEX and JSE) where the estimated values of $d$ are, respectively, 0.96 and 0.88 and the I(1) hypothesis is rejected in favour of lower orders of integration (mean reversion).

We also conducted a semiparametric approach based on the Whittle function (Robinson, 1995; Abadir et al., 2007), but not imposing any specific form for the error term. The results, for a selected group of bandwidth numbers $(\mathrm{m})$ are displayed across Table $2 .^{3}$

\section{[Insert Table 2 about here]}

Starting with the real estate indices, we observe evidence of unit roots for the cases of China, India and Russia. For Brazil, the estimated values seem to be higher than 1 in

\footnotetext{
${ }^{2}$ Though not reported, we also conducted standard unit root methods (Dickey and Fuller, ADF, 1979; Phillips and Perron, PP, 1988; Elliot et al., ERS, 1996; Ng and Perron, NP, 2001), and the results supported the I(1) specification in all cases.

${ }^{3}$ The choice of the bandwidth number, m, clearly shows the trade-off between bias and variance of d: the asymptotic variance is decreasing with $\mathrm{m}$ while the bias is growing with $\mathrm{m}$. In most empirical applications the value $\mathrm{m}=(\mathrm{T})^{0.5}$ is chosen.
} 
some cases, and the contrary happens for South Africa, with values below 1. For the stocks, evidence of unit roots was observed in China and India; values higher than 1 for some bandwidth numbers in Brazil, and estimates of d below 1 for Russia and South Africa. Nevertheless, all the values in all cases where close to 1, and performing vis-à-vis methods (Robinson and Yajima, 2002) to test the homogeneity condition in the orders of integration between the ENEIs and the stocks for each country, we could not reject the hypothesis of equal degrees of integration in any single case, supporting thus the analysis of cointegration. Results based on logged transformed series were very similar to those presented across Tables 1 and 2 so that they are not reported here.

In the cointegrating setting, the first thing we do is to perform Engle and Granger's (1987) two step approach, regressing first one variable against the other in each relationship, i.e.,

$$
E N E_{t}=\beta_{0}+\beta_{1} S P_{t}+x_{t},
$$

where $E N E_{t}$ and $S P_{t}$ are the logged transformed time series under investigation, and testing then the order of integration of the estimated errors. This, in fact is the approach proposed in Cheung and Lai (1993) and Gil-Alana (2003), which basically generalizes the concept and ideas in Engle and Granger (1987) to the fractional case. In doing so, the results, based on the appropriate critical values, are reported in Table 3.

\section{[Insert Tables 3 and 4 about here]}

We observe that, apart from South Africa, the estimated values of $d$ are around 1, which is consistent with the hypothesis of no cointegration. For South Africa, however, we found some small degree of mean reverting behaviour, with an order of integration that is significantly smaller than 1 . 
Based on this lack of cointegration, our next approach consists of using Robinson's (1994) set-up and considering simultaneously the following model,

$$
E N E_{t}=\beta_{01}+\beta_{11} S P_{t}+x_{t}, \quad(1-L)^{d} x_{t}=u_{t}, \quad t=1,2, \ldots,
$$

estimating all the parameters in the model at the same time and assuming that the stock prices are exogenous in the determination of the real estate indices ${ }^{4}$ That means that equation (4) can be re-expressed as

$$
(1-L)^{d} E N E_{t}=\beta_{01}(1-L)^{d} 1_{t}+\beta_{11}(1-L)^{d} S P_{t}+u_{t}, \quad t=1,2, \ldots
$$

and thus the two series display the same degree of integration and once d-differenced, the residuals are expected to be $\mathrm{I}(0)$. The results obtained based on the model specification above are displayed in Table 4 . We observe that the estimated values of $d$ are equal to or about 1 in all cases; however, this approach imposes the error term to be $\mathrm{I}(0)$ which might be a strong assumption to be satisfied by the data. Because of that, in the last table, we conduct the regression based on the growth rates, regressing the first differenced of the ENEIs against the first differences of the stocks (in logs) and testing the order of integration of the residuals to verify that no long memory is present in them. The results are reported in Table 5 .

\section{[Insert Table 5 about here]}

We see there is no evidence of long memory (i.e., significant positive values of d) in any single case, and the estimated coefficient for the relationship between the two variables is statistically significant and positive in all cases, with the lowest value obtained in Russia, followed by China and South Africa, and the largest ones corresponding to Brazil and especially India.

\footnotetext{
${ }^{4}$ Robinson's (1994) method employed here is based on the frequency domain. A time domain version of this method is given in Tanaka (1999).
} 
Causality (in Granger's sense), either in one direction or both directions is not explained by cointegration since the essence of cointegration is to obtain a long run regression, while causality tells us if one variable causes the other. Following Granger's (1969) causality test, for example, we investigate whether $E N E_{t}$ causes $S P_{t}$, that is to see how much of the current $E N E_{t}$ can be explained by past values of $E N E_{t}$ and then to see whether adding lagged values of $S P_{t}$ (that is $S P_{t-1}, S P_{t-2}, \ldots, S P_{t-k}$ ) can help to explain its behaviour. Thus, $E N E_{t}$ is said to be Granger-caused by $S P_{t}$ if $S P_{t}$ helps in predicting $E N E_{t}$ . This can be a two way causation, given in Vector AutoRegressive (VAR) form:

$$
\begin{gathered}
E N E_{t}=\alpha_{0}+\alpha_{1} E N E_{t-1}+\ldots+\alpha_{k} E N E_{t-k}+\beta_{1} S P_{t-1}+\ldots+\beta_{k} S P_{-k}+u_{t} \\
S P_{t}=\alpha_{0}+\alpha_{1} S P_{t-1}+\ldots+\alpha_{k} S P_{t-k}+\beta_{1} E N E_{t-1}+\ldots+\beta_{k} E N E_{-k}+u_{t},
\end{gathered}
$$

for all possible pairs of $\left(E N E_{t}, S P_{t}\right)$. The reported $\mathrm{F}$ statistics, in Table 6, are the Wald statistics for the joint hypothesis:

$$
H_{0}: \beta_{1}=\beta_{2}=\ldots=\beta_{k}=0
$$

for each equation. The null hypothesis is that $S P_{t}$ does not Granger-cause $E N E_{t}$ in (6), and that $E N E_{t}$ does not Granger-cause $S P_{t}$ in (7). As earlier explained, the existence of causation running from real estate index $\left(E N E_{t}\right)$ to stocks $\left(S P_{t}\right)$ implies "credit effect", while causation running from stocks $\left(S P_{t}\right)$ to real estate index $\left(E N E_{t}\right)$ implies "wealth effect".

\section{[Insert Table 6 about here]}

The results can be summarized as follows: for Brazil and China, we do not observe significant Granger-causality in either of the two directions, while we observe causality in both directions in the case of South Africa, and this is up to the third month; thus, we confirm 
the existence of both "wealth effect" and "credit effect". In India and Russia, the causality runs from real estate stocks to general stocks giving support to "credit effects" only. These results imply that, in the case of South Africa, both housing and stocks are relatively more expensive and lucrative and these two assets serve as means of investment. Thus, there is diversification benefits in real estate listed stocks and general stocks in the three countries (Russia, India, South Africa, RIS) on the short-run, while in the overall, market segmentation between real estate stocks and general stocks remains.

\section{Concluding remarks}

In this paper, we have examined the relationship between the real estate market and the stock indices in the BRICS countries by using both long memory (fractional integration and cointegration) methods and causality test.

Our results based on fractional integration (univariate) methods indicate that all series are highly persistent, with orders of integration which are around 1 in the majority of the series. In fact, we only observe a small degree of mean reversion in the case of the two South African series. This lack of reversion in the other series indicates that shocks will have permanent effects, requiring strong policy measures to recover the original trends. Based on this evidence against mean reversion, and supporting the I(1) models, we conducted a (fractionally) cointegrated analysis, and the results do not report any evidence supporting a long run equilibrium relationship between the real estate indices and the stock indices in the BRICS countries. Looking at the causality between the two variables in Granger's sense, we obtain evidence supporting causality in both directions ("wealth" and "credit" effects) in the case of South Africa, and causality running from real estate stocks to stocks ("credit" effects) in the cases of India and Russia. The results obtained in this paper 
may serve as guide to asset and portfolio managers in the BRICS countries, particularly in the RIS countries where there is possible diversification benefits between real estate stocks and stocks, in the short run.

Su (2011) noted that the empirical evidence of the relationship between real estate stocks and stocks is inconclusive though convincing, and noting that fractional integration and cointegration methodologies rely on linearity and unit root assumptions, we therefore recommend an alternative estimation framework to further validate our work, particularly, taking into account the non-linear properties of the adjustment time series process. One of such contagion methodologies is detailed in Breitung (2001), which demonstrates power in both linear and non-linear frameworks, and is applicable to any data generating process. Accordingly, the method of Cuestas and Gil-Alana (2016) that allows for fractional integration in the context of nonlinearities can also be applicable. Another possible extension of this work is that since this work is limited to the BRICS countries, we can extend it to other countries in the world, using datasets after the global crisis of 2009, based on availability of longer datasets, and looking at periods before the global financial crisis as well. 


\section{References}

Abadir, K.M., W. Distaso and L. Giraitis (2007) Nonstationarity-extended local Whittle estimation, Journal of Econometrics 141, 1353-1384.

Abbritti, M., Gil-Alana, L.A., Lovcha, Y. and Moreno, A. (2016). Term Structure Persistence. Journal of Financial Econometrics, 14 (2), 331-352.

Anoruo, E.A. and Elike, U. (2015). Empirical evidence on the Asymmetric Relationship between Bond and REIT returns. International Journal of Financial Research, 6(3), 1-12.

Baillie, R. T. (1996). Long memory processes and fractional integration in econometrics. Journal of Econometrics, 73 (1), 5-59.

Bloomfield, P., (1973). An exponential model in the spectrum of a scalar time series. Biometrika, 60(2), 217-226.

Breitung, J. (2001). Rank Test for Nonlinear Cointegration. Journal of Business and Economic Statistics, 19(3), 331-340.

Chang, T-Y., Fang, H. and Lee, Y-H. (2015). Nonlinear adjustment to the long-run equilibrium between the REIT and the stock markets in Japan and Singapore. Romanian Journal of Economic and Forecasting, XVIII(3), 27-38.

Cheung, Y.W. and Lai, K.S. (1993). A fractional cointegration analysis of purchasing power parity. Journal of Business and Economic Statistics, 11, 103-112.

Cuestas, J.C. and L.A. Gil-Alana, (2016), A nonlinear approach with long range dependence based on Chebyshev polynomials, Studies in Nonlinear Dynamics and Econometrics 20,57-94.

Dickey, D.A and Fuller, W. A. (1979) Distributions of the Estimators for Autoregressive Time Series with a Unit Root, Journal of American Statistical Association, 74, 366, 427 481.

Elliot, G., Rothenberg, T.J and Stock, J.H. (1996) Efficient Tests for an Autoregressive Unit Root, Econometrica, 64, 813-836.

Engle, R.F. and Granger, C.W.J. (1987). Cointegration and error correction: Representation, estimation and testing. Econometrica 55, 251-276.

Gil-Alana, L.A. (2003). Testing of Fractional Cointegration in Macroeconomic Time Series, Oxford Bulletin of Economic and Statistics, 65(4), 517-529.

Gil-Alana, L.A. and Hualde, J. (2009). Fractional integration and cointegration. An overview with an empirical application. The Palgrave Handbook of Applied Econometrics, Volume 2. Edited by Terence C. Mills and Kerry Patterson, MacMillan Publishers, pp. 434472. 
Gil-Alana, L.A. and Moreno, A. (2012). Uncovering the US term premium, Journal of Banking and Finance, 36(4), 1181-1193.

Gil-Alana, L.A. and Robinson, P.M. (1997). Testing of unit roots and other nonstationary hypotheses in macroeconomic time series, Journal of Econometrics, 80 (2), 241-268.

Granger, C.W.J. (1969). Investigating causal relations by Econometric models and Crossspectral methods. Econometrica, 37(3), 424-438.

Granger, C.W.J. (1980). Long memory relationships and the aggregation of dynamic models, Journal of Econometrics14, 227-238.

Granger, C.W.J. (1981). Some properties of Time Series data and their use in Econometric Model Specification, Journal of Econometrics, 16, 121-131.

Granger, C.W.J. and Joyeux, R. (1980). An introduction to long-memory time series models and fractional differencing. Journal of Time Series Analysis, 1, 15-29.

Gyourko, J. and Keim, D.B. (1992). What does the stock market tell us about real estate returns? Real Estate Economies, 20(3), 457-485.

Hualde, J. and Robinson, P.M. (2007). Root-n-consistent estimation of weak fractional cointegration. Journal of Econometrics, 140, 450-484.

Hualde, J. and Robinson, P.M. (2010). Semiparametric estimation of fractional cointegration. Journal of Econometrics, 157, 492-511.

Johansen, S. and M.Ø. Nielsen (2010) Likelihood inference for a nonstationary fractional autoregressive model, Journal of Econometrics 158, 51-66.

Johansen, S. and M.Ø. Nielsen (2012) Likelihood inference for a Fractionally Cointegrated Vector Autoregressive Model, Econometrica 80(6), 2667-2732.

Lee, M-T., Lee, C.L., Lee, M-L. and Liao, C-Y. (2017). Price linkages between Australia housing and stock markets: Wealth effect, credit effect or capital switching? International Journal of Housing Markets and Analysis, 10(2), 305-323.

Lin, T.C. and Lin, Z-H. (2011). Are stock and real estate markets integrated? An Empirical Study of Six Asian Economies. Pacific-Basin Finance Journal, 19(5), 571-585.

Lin, P. and Fuerst, F. (2014). The integration of direct real estate and stock markets in Asia. Applied Economics, 46(12), 1323-1334.

Liu, C. H., Hartzell, D.J., Greig, W. and Grissom, T.V. (1990). The integration of the real estate market and the stock market: Some preliminary evidence. The Journal of Real Estate Finance and Economics, 3(3), 261-282. 
Liu, Y-S. and Su, C-W. (2010). The relationship between the real estate and stock markets of China: Evidence from a nonlinear model. Applied Financial Economics, 20(22), 17411749 .

Lobato, I.N. and Savin, N.E. (1998), Real and Spurious long memory properties of stock markets, Journal of Business and Economic Statistics, 16 (3), 261-268.

Michelacci, C. and Zaffaroni, P. (2000). Fractional (Beta) convergence, Journal of Monetary Economics, 45(1), 129-153.

Ng, S. and P. Perron (2001) Lag Length Selection and the Construction of Unit Root Tests with Good Size and Power, Econometrica 69, 1519-1554.

Pandey, R. and Jessica, V.M. (2016). Real estate investment: An Alternative Diversifier for Indian Financial Market. Indone Management Journal, 8(2), 27-32.

Petrova, T. (2010). What are the effects of housing prices and the REIT index in Bulgaria on the Bulgarian stock exchange index? The Park Place Economist, 18(1), 41-47.

Phillips, P.C.B. and P. Perron (1988) Testing for a unit root in time series regression, Biometrika 75, 2, 335-346.

Robinson, P.M. (1994) Efficient tests of nonstationary hypotheses, Journal of the American Statistical Association 89, 1420-1437.

Robinson, P.M. (1995) Gaussian semi-parametric estimation of long range dependence, Annals of Statistics 23, 1630-1661.

Robinson, P.M. and Hualde, J. (2003), Cointegration in fractional systems with unknown integration order, Econometrica, 71, 6, 1727-1766.

Robinson, P. M. and Marinucci, D. (2001). Narrow-band analysis of nonstationary processes. Annals of Statistics, 29, 947-986.

Robinson, P. M. and Yajima, Y. (2002). Determination of cointegrating rank in fractional systems. Journal of Econometrics, 106, 217-24.

$\mathrm{Su}, \mathrm{C}-\mathrm{W}$. (2011). Non-linear causality between the stock and real estate markets of Western European countries: Evidence from rank tests. Economic Modelling, 28, 845-851.

Tanaka, K. (1999), The nonstationary fractional unit root, Econometric Theory 15, 249-264.

Toda, H. Y. and Yamamoto, T. (1995). Statistical inference in vector autoregressions with possibly integrated processes Journal of Econometrics, 66, 225-250.

Tsai, I-C. Lee, C-F. and Chiang, M.C. (2012). The Asymmetric Wealth Effect in the US Housing and Stock Markets: Evidence from the Threshold Cointegration model. The Journal of Real Estate Finance and Economics, 45(4), 1005-1020. 
Wang, Y-C., Huang, R., Nieh, C-C., Ou, H-K. and Chi, M. (2017). Integration between real estate market and stock market: Evidence from Taiwan. Applied System Innovation (ICASI) Conference Proceeding, NSPEC Accession Number 17059043.

Yuksel, A. (2016). The relationship between stock and real estate prices in Turkey: Evidence around the global financial crisis. Central Bank Review, 16(1), 33-40. 
Figure 1: Plots of REIT and Stock índex of BRICS
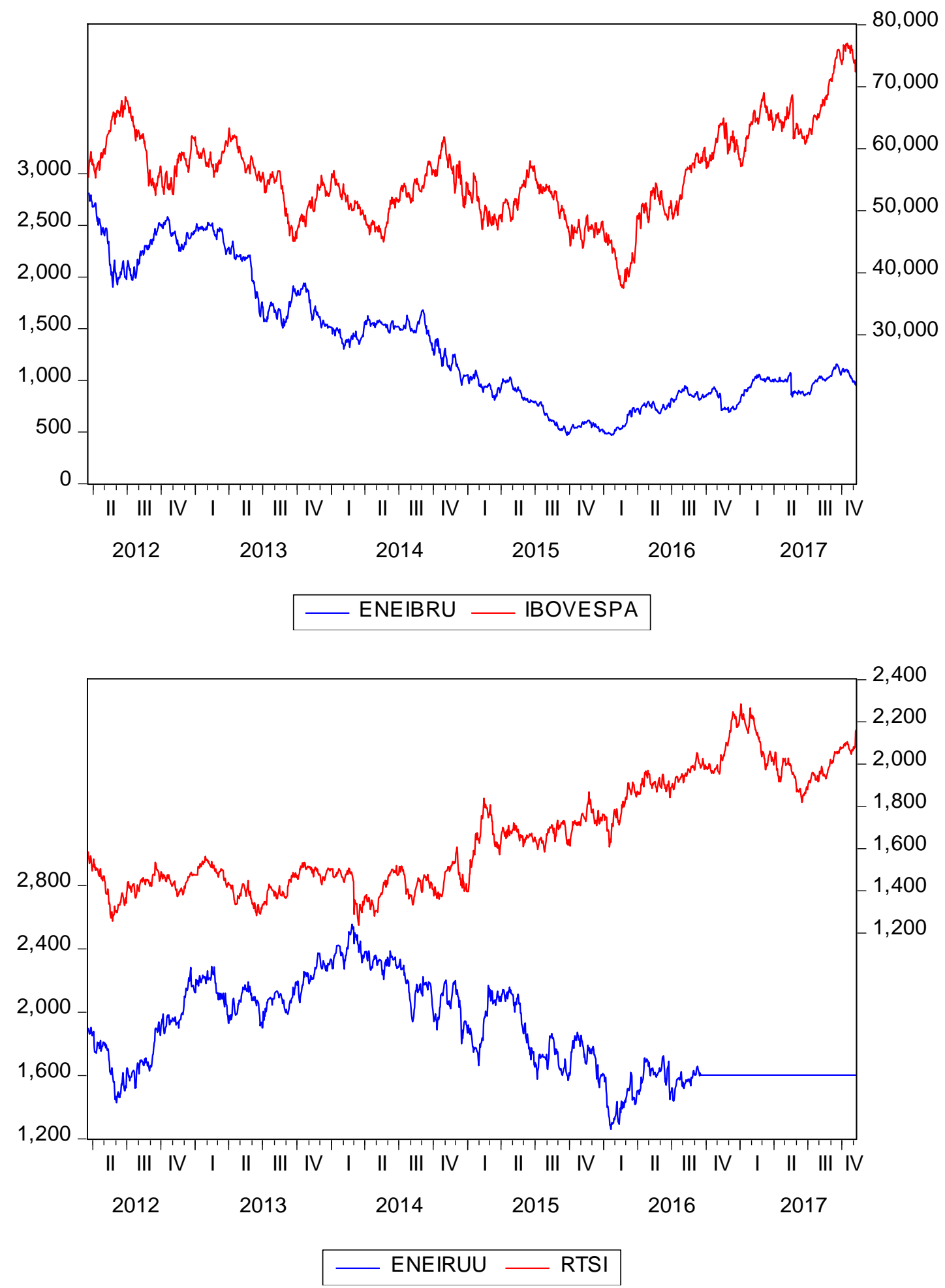

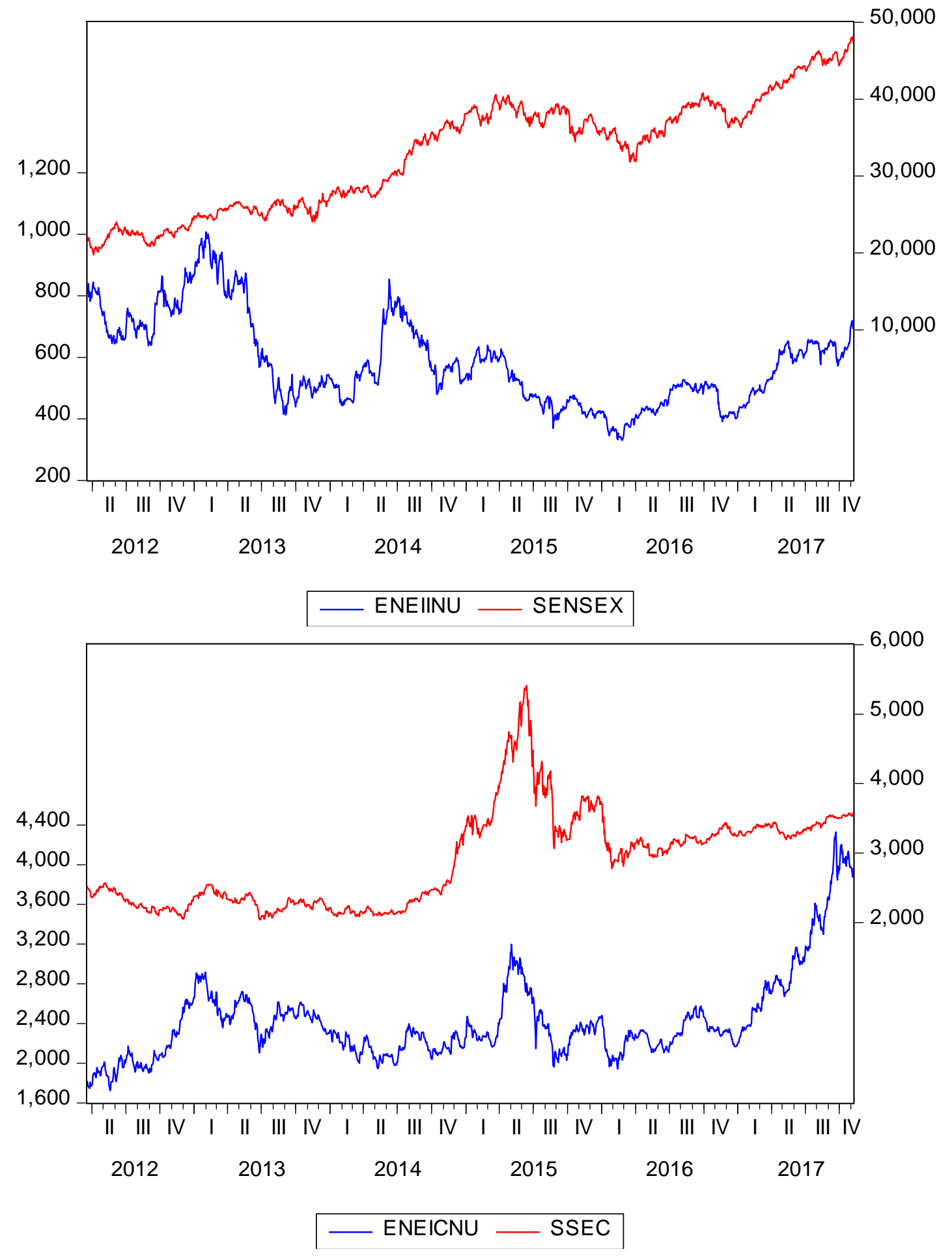


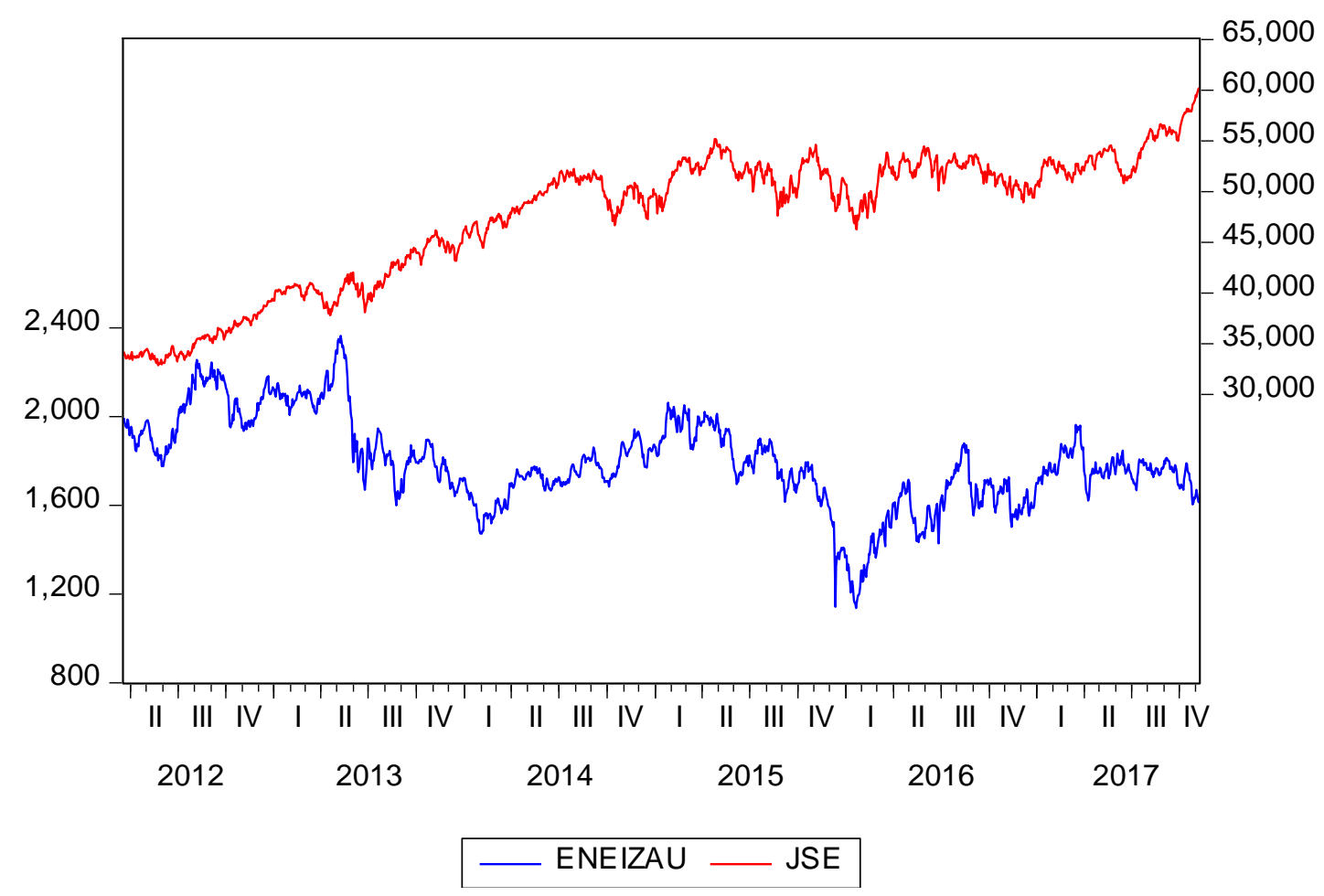


Table 1: Estimates of $\mathbf{d}$ for each of the individual series

\begin{tabular}{|c|c|c|c|c|}
\hline \multicolumn{5}{|c|}{ i) No autocorrelation } \\
\hline Cou & Series & No terms & Intercept & Time trend \\
\hline \multirow{2}{*}{ BRAZIL } & ENEIBRU & $1.00(0.96,1.04)$ & $1.05(1.02,1.09)$ & $1.05(1.02,1.09)$ \\
\hline & IBOV & $0.99(0.96,1.03)$ & $1.02(0.98,1.06)$ & $1.02(0.98,1.06)$ \\
\hline \multirow{2}{*}{ CHINA } & $\mathrm{U}$ & $1.01(0.98,1.05)$ & $1.06(1.02,1.11)$ & $1.06(1.02,1.11)$ \\
\hline & RTSI & $1.01(0.97,1.05)$ & $1.05(1.01,1.09)$ & $1.05(1.01,1.09)$ \\
\hline \multirow{2}{*}{ INDIA } & ENEIINU & $1.02(0.99,1.06)$ & $1.05(1.01,1.09)$ & $1.05(1.01,1.09)$ \\
\hline & SENSEX & $1.00(0.96,1.04)$ & $1.04(1.00,1.08)$ & $1.04(1.00,1.08)$ \\
\hline \multirow{2}{*}{ RUSSIA } & ENE & $0.99(0.95,1.03)$ & $1.00(0.96,1.04)$ & $1.00(0.96,1.04)$ \\
\hline & SSEC & $1.06(0.96,1.04)$ & $0.99(0.96,1.03)$ & $0.99(0.96,1.03)$ \\
\hline \multirow{2}{*}{$\begin{array}{l}\text { SOUTH } \\
\text { AFRICA }\end{array}$} & ENEIZAU & $0.99(0.96,1.03)$ & $1.02(0.98,1.07)$ & $1.02(0.98,1.07)$ \\
\hline & JSE & $0.99(0.95,1.03)$ & $0.94(0.91,0.99)$ & $0.94(0.91,0.99)$ \\
\hline \multicolumn{5}{|c|}{ ii) With autocorrelation } \\
\hline Co & Series & No terms & Int & trend \\
\hline \multirow{2}{*}{ BRAZIL } & ENEIBRU & $0.96(0.91,1.03)$ & $1.02(0.97,1.09)$ & $1.02(0.97,1.09)$ \\
\hline & IBOVESPA & $0.96(0.91,1.03)$ & $1.00(0.95,1.06)$ & $1.00(0.95,1.06)$ \\
\hline \multirow{2}{*}{ CHINA } & ENEIRUU & $0.98(0.94,1.04)$ & $0.97(0.92,1.03)$ & $0.97(0.92,1.03)$ \\
\hline & TSI & $1.00(0.93,1.06)$ & $0.98(0.93,1.04)$ & $0.98(0.93,1.04)$ \\
\hline \multirow{2}{*}{ INDIA } & ENEIINU & $1.00(0.95,1.06)$ & $1.00(0.94,1.06)$ & $1.00(0.94,1.06)$ \\
\hline & SENSEX & $0.98(0.93,1.04)$ & $0.96(0.91,1.02)$ & $0.96(0.91,1.02)$ \\
\hline \multirow{2}{*}{ RUSSIA } & ENEICNU & $0.97(0.92,1.04)$ & $0.97(0.91,1.05)$ & $0.97(0.91,1.05)$ \\
\hline & SSEC & $1.01(0.95,1.07)$ & $0.96(0.90,1.03)$ & $0.96(0.90,1.03)$ \\
\hline \multirow{2}{*}{$\begin{array}{r}\text { SOUTH } \\
\text { AFRICA }\end{array}$} & ENEIZAU & $0.96(0.91,1.02)$ & $0.91(0.86,0.98)$ & $0.91(0.86,0.98)$ \\
\hline & JSE & $1.00(0.93,1.05)$ & $0.88(0.83,0.95)$ & $0.88(0.83,0.95)$ \\
\hline
\end{tabular}

In bold, the selected models according to the deterministic terms. 
Table 2: Semiparametric estimates of $d$

\begin{tabular}{|c|c|c|c|c|c|}
\hline \multicolumn{6}{|c|}{ i) REIT } \\
\hline & BRAZIL & CHINA & INDIA & RUSSIA & S. AFRICA \\
\hline 30 & 1.072 & 1.042 & 0.976 & 0.877 & 0.710 \\
\hline 31 & 1.070 & 1.036 & 0.957 & 0.871 & 0.720 \\
\hline 32 & 1.093 & 1.028 & 0.958 & 0.889 & 0.735 \\
\hline 33 & 1.120 & 1.046 & 0.958 & 0.904 & 0.744 \\
\hline 34 & 1.146 & 1.051 & 0.964 & 0.901 & 0.757 \\
\hline 35 & 1.155 & 1.058 & 0.981 & 0.886 & 0.770 \\
\hline 36 & 1.152 & 1.058 & 0.991 & 0.868 & 0.791 \\
\hline 37 & 1.154 & 1.076 & 0.989 & 0.880 & 0.791 \\
\hline 38 & 1.157 & 1.081 & 0.974 & 0.895 & 0.806 \\
\hline 39 & 1.177 & 1.087 & 0.984 & 0.911 & 0.824 \\
\hline 40 & 1.197 & 1.054 & 0.997 & 0.914 & 0.844 \\
\hline \multicolumn{6}{|c|}{ ii) STOCKS } \\
\hline & BRAZIL & CHINA & INDIA & RUSSIA & S. AFRICA \\
\hline 30 & 1.046 & 1.101 & 0.934 & 0.715 & 0.795 \\
\hline 31 & 1.046 & 1.072 & 0.950 & 0.733 & 0.803 \\
\hline 32 & 1.068 & 1.075 & 0.960 & 0.745 & 0.815 \\
\hline 33 & 1.090 & 1.042 & 0.956 & 0.763 & 0.824 \\
\hline 34 & 1.102 & 1.025 & 0.865 & 0.784 & 0.827 \\
\hline 35 & 1.112 & 1.038 & 0.978 & 0.799 & 0.821 \\
\hline 36 & 1.128 & 1.048 & 0.997 & 0.819 & 0.830 \\
\hline 37 & 1.149 & 1.057 & 1.015 & 0.834 & 0.835 \\
\hline 38 & 1.141 & 1.055 & 0.982 & 0.804 & 0.833 \\
\hline 39 & 1.157 & 1.034 & 0.988 & 0.820 & 0.844 \\
\hline 40 & 1.168 & 1.018 & 0.991 & 0.834 & 0.828 \\
\hline
\end{tabular}

In bold, evidence of unit roots or I(1) behaviour at the 5\% level. 
Table 3: Estimated orders of integration in (2)

\begin{tabular}{|c|c|c|c|}
\hline & \multicolumn{2}{|c|}{ No autocorrelation } & \multicolumn{2}{|c|}{ Autocorrelation } \\
\hline BRAZIL & $0.98(0.94,1.02)$ & $0.96(0.91,1.02)$ \\
\hline CHINA & $1.06(1.02,1.11)$ & $0.95 \quad(0.91,1.01)$ \\
\hline INDIA & $1.05(1.01,1.10)$ & $1.01 \quad(0.94,1.06)$ \\
\hline RUSSIA & $1.02(0.98,1.07)$ & $0.96(0.91,1.03)$ \\
\hline SOUTH AFRICA & $1.01 \quad(0.96,1.05)$ & $0.90(0.82,0.94)$ \\
\hline
\end{tabular}

Table 4: Estimated orders of integration in (3)

\begin{tabular}{|c|cc|cc|}
\hline & \multicolumn{2}{|c|}{ No autocorrelation } & \multicolumn{2}{c|}{ Autocorrelation } \\
\hline BRAZIL & 1.01 & $(0.95,1.05)$ & 0.99 & $(0.95,1.06)$ \\
\hline CHINA & 1.05 & $(1.01,1.10)$ & $0.95 \quad(0.90,1.02)$ \\
\hline INDIA & $1.01 \quad(0.97,1.05)$ & $0.96 \quad(0.91,1.02)$ \\
\hline RUSSIA & $0.98 \quad(0.95,1.02)$ & $0.97 \quad(0.91,1.04)$ \\
\hline SOUTH AFRICA & $0.99 \quad(0.95,1.03)$ & $0.90 \quad(0.85,0.96)$ \\
\hline
\end{tabular}


Table 5: Estimates based on growth rate regressions

\begin{tabular}{|c|c|c|c|c|c|c|}
\hline \multirow{2}{*}{ Country } & \multicolumn{3}{|c|}{ No autocorrelation } & \multicolumn{3}{c|}{ Autocorrelation } \\
\cline { 2 - 7 } & $\begin{array}{c}\mathrm{d} \\
(95 \% \mathrm{ci})\end{array}$ & $\begin{array}{c}\text { Intercept } \\
\text { (t-value) }\end{array}$ & $\begin{array}{c}\text { Trend } \\
(\mathrm{t}-\text {-value })\end{array}$ & $\begin{array}{c}\mathrm{d} \\
\text { (95\% ci) }\end{array}$ & $\begin{array}{c}\text { Intercept } \\
\text { (t-value) }\end{array}$ & $\begin{array}{c}\text { Trend } \\
\text { (t-value) }\end{array}$ \\
\hline \multirow{2}{*}{ BRAZIL } & 0.01 & -0.00039 & $\mathbf{1 . 0 4 8 6 2}$ & -0.01 & -0.00039 & $\mathbf{1 . 0 4 9 7 5}$ \\
& $(-0.03,0.04)$ & $(-1.64)$ & $\mathbf{( 7 4 . 2 3 )}$ & $(-0.07,0.06)$ & $(-1.88)$ & $\mathbf{7 4 . 3 6 )}$ \\
\hline \multirow{2}{*}{ CHINA } & 0.05 & -0.00042 & $\mathbf{0 . 5 3 2 6 8}$ & -0.04 & -0.00037 & $\mathbf{0 . 5 3 6 2 9}$ \\
& $(0.01,0.09)$ & $(-0.88)$ & $\mathbf{( 2 0 . 8 8 )}$ & $(-0.09,0.02)$ & $(-1.39)$ & $\mathbf{( 2 1 . 2 2 )}$ \\
\hline \multirow{2}{*}{ INDIA } & 0.01 & -0.00102 & $\mathbf{1 . 7 5 6 3 1}$ & -0.04 & -0.00105 & $\mathbf{1 . 7 6 4 1 0}$ \\
& $(-0.03,0.05)$ & $(-2.43)$ & $\mathbf{( 3 9 . 8 7 )}$ & $(-0.09,0.02)$ & $(-3.51)$ & $\mathbf{( 4 0 . 2 6})$ \\
\hline \multirow{2}{*}{ RUSSIA } & -0.02 & -0.00020 & $\mathbf{0 . 4 0 2 6 2}$ & -0.03 & -0.00020 & $\mathbf{0 . 4 0 4 0 2}$ \\
& $(-0.05,0.02)$ & $(-0.60)$ & $\mathbf{( 1 2 . 1 2})$ & $(-0.09,0.04)$ & $(-0.65)$ & $\mathbf{( 1 2 . 1 7 )}$ \\
\hline \multirow{2}{*}{ S. AFRICA } & -0.01 & -0.00039 & $\mathbf{0 . 6 7 5 3 3}$ & -0.10 & -0.00038 & $\mathbf{0 . 6 9 0 3 9}$ \\
& $(-0.04$, & $(-1.01)$ & $\mathbf{( 1 4 . 3 2 )}$ & $-0.15,-$ & $(-1.85)$ & $\mathbf{( 1 4 . 6 6 )}$ \\
& $0.03)$ & & & $0.04)$ & & \\
\hline
\end{tabular}

In bold, significant coefficients at the 5\% level. 
Table 6: Pairwise Granger Causality test

\begin{tabular}{|c|c|c|c|c|}
\hline Country & & Lag & F-Statistic & Prob. \\
\hline \multirow[t]{2}{*}{ BRAZIL } & $\begin{array}{l}\text { IBOVESPA does not Granger Cause } \\
\text { ENEIBRU }\end{array}$ & $\begin{array}{l}1 \\
2 \\
3 \\
\end{array}$ & $\begin{array}{l}0.5646 \\
0.2443 \\
0.7523 \\
\end{array}$ & $\begin{array}{l}0.4525 \\
0.6321 \\
0.5210 \\
\end{array}$ \\
\hline & $\begin{array}{l}\text { ENEIBRU does not Granger Cause } \\
\text { IBOVESPA }\end{array}$ & $\begin{array}{l}1 \\
2 \\
3\end{array}$ & $\begin{array}{l}0.2906 \\
0.4588 \\
0.3767\end{array}$ & $\begin{array}{l}0.5899 \\
0.6321 \\
0.7698\end{array}$ \\
\hline \multirow[t]{2}{*}{ RUSSIA } & RTSI does not Granger Cause ENEIRUU & $\begin{array}{l}1 \\
2 \\
3\end{array}$ & $\begin{array}{l}2.0028 \\
2.2809 \\
1.5310\end{array}$ & $\begin{array}{l}0.1572 \\
0.1026 \\
0.2046\end{array}$ \\
\hline & ENEIRUU does not Granger Cause RTSI & $\begin{array}{l}1 \\
2 \\
3 \\
\end{array}$ & $\begin{array}{l}9.7793 \\
8.3314 \\
5.6209\end{array}$ & $\begin{array}{l}0.0018 \\
0.0003 \\
0.0008 \\
\end{array}$ \\
\hline \multirow[t]{2}{*}{ INDIA } & SENSEX does not Granger Cause ENEIINU & $\begin{array}{l}1 \\
2 \\
3\end{array}$ & $\begin{array}{l}0.1311 \\
1.9770 \\
1.578\end{array}$ & $\begin{array}{l}0.7173 \\
0.1389 \\
0.2541 \\
\end{array}$ \\
\hline & ENEIINU does not Granger Cause SENSEX & $\begin{array}{l}1 \\
2 \\
3\end{array}$ & $\begin{array}{l}1.4785 \\
\mathbf{3 . 1 0 8 1} \\
\mathbf{2 . 6 3 4 6}\end{array}$ & $\begin{array}{l}0.2242 \\
0.0450 \\
0.0484\end{array}$ \\
\hline \multirow[t]{2}{*}{ CHINA } & SSEC does not Granger Cause ENEICNU & $\begin{array}{l}1 \\
2 \\
3\end{array}$ & $\begin{array}{l}0.2047 \\
0.0934 \\
2.3689\end{array}$ & $\begin{array}{l}0.6510 \\
0.9109 \\
0.0690\end{array}$ \\
\hline & ENEICNU does not Granger Cause SSEC & $\begin{array}{l}1 \\
2 \\
3\end{array}$ & $\begin{array}{l}0.6583 \\
0.9305 \\
0.6841\end{array}$ & $\begin{array}{l}0.4173 \\
0.9460 \\
0.5618 \\
\end{array}$ \\
\hline \multirow[t]{2}{*}{$\begin{array}{l}\text { SOUTH } \\
\text { AFRICA }\end{array}$} & SSEC does not Granger Cause ENEICNU & $\begin{array}{l}1 \\
2 \\
3\end{array}$ & $\begin{array}{l}6.3347 \\
3.6947 \\
2.5321\end{array}$ & $\begin{array}{l}0.0119 \\
0.0251 \\
0.0272\end{array}$ \\
\hline & ENEICNU does not Granger Cause SSEC & $\begin{array}{l}1 \\
2 \\
3\end{array}$ & $\begin{array}{l}0.7220 \\
\mathbf{4 . 6 7 9 8} \\
\mathbf{3 . 3 5 7 6}\end{array}$ & $\begin{array}{l}0.3956 \\
0.0094 \\
0.0051\end{array}$ \\
\hline
\end{tabular}

In bold, significant causality test at 5\% level 